\title{
Vaccinomics and Adversomics in the Era of Precision Medicine: A Review Based on HBV, MMR, HPV, and COVID-19 Vaccines
}

\author{
Jasna Omersel and Nataša Karas Kuželički * \\ Faculty of Pharmacy, University of Ljubljana, Aškerčeva cesta 7, 1000 Ljubljana, Slovenia; \\ jasna.omersel@ffa.uni-lj.si \\ * Correspondence: natasa.karaskuzelicki@ffa.uni-lj.si; Tel.: +386-1-476-9-629
}

Received: 25 September 2020; Accepted: 2 November 2020; Published: 5 November 2020

\begin{abstract}
Precision medicine approaches based on pharmacogenomics are now being successfully implemented to enable physicians to predict more efficient treatments and prevention strategies for a given disease based on the genetic background of the patient. This approach has already been proposed for vaccines, but research is lagging behind the needs of society, and precision medicine is far from being implemented here. While vaccinomics concerns the effectiveness of vaccines, adversomics concerns their side effects. This area has great potential to address public concerns about vaccine safety and to promote increased public confidence, higher vaccination rates, and fewer serious adverse events in genetically predisposed individuals. The aim here is to explore the contemporary scientific literature related to the vaccinomic and adversomic aspects of the three most-controversial vaccines: those against hepatitis B, against measles, mumps, and rubella, and against human Papilloma virus. We provide detailed information on the genes that encode human leukocyte antigen, cytokines and their receptors, and transcription factors and regulators associated with the efficacy and safety of the Hepatitis B and Measles, Mumps and Rubella virus vaccines. We also investigate the future prospects of vaccinomics and adversomics of a COVID-19 vaccine, which might represent the fastest development of a vaccine ever.
\end{abstract}

Keywords: adversomics; COVID-19; genetics; hepatitis B; human Papilloma virus; MMR vaccine; precision medicine; vaccinomics

\section{Introduction}

Despite some initial skepticism, it is undeniable that the era of precision (or personalized) medicine is here, as formalized by the launch of the Precision Medicine Initiative in 2015 [1]. The paradigm that one size does not fit all is slowly taking hold in the minds of clinicians, and also of patients, and by society as a whole. What is more, we are starting to realize that personalized approaches might be a solution to the public distrust in medicines, pharmaceutical companies, and science in general that has emerged over the last few decades, and mainly in developed countries.

One of the first fields of precision medicine that developed was pharmacogenomics, which provided both the scientific basis and clinical outcomes that have together promoted the practice of personalized drug therapies; i.e., prescribing each patient with the right dose of the right drug, thus maximizing the efficiency and safety of the therapy [2]. The application of this same principle to vaccines has been named vaccinogenomics, or vaccinomics. The term vaccinomics was first used by Hoffman et al. in 1998 [3] and extensively studied by Gregory A. Poland and the Mayo Clinic Vaccine Research Group [4]. By definition, vaccinomics explores the influence of genetic (and non-genetic) factors on the heterogeneity of vaccine-induced immune responses between individuals 
and populations [5]. While vaccinomics has been more focused on vaccine effectiveness, the field of adversomics was again first introduced by Poland, this time in 2009, and this is more concerned about the side effects of vaccines [6].

As both of these fields are at most a decade old, relatively little research has been carried out here compared to pharmacogenomics. Interestingly, most of the studies in the field of personalized vaccinology have investigated vaccine effectiveness, with only a few relating to vaccine-induced side effects. This is demonstrated by the number of PubMed papers on vaccinomics and adversomics over the last 10 years to date, at 334 and 65, respectively. While vaccine effectiveness has been studied for most of the existing vaccines [2], adversomic studies have mainly been carried out for the vaccines against smallpox (Variola virus) and measles, mumps, and rubella (MMR) viruses [7]. Although vaccine effectiveness is indeed a very important issue, especially from the financial point of view, the adversomics of vaccines also need to be developed further as they hold great potential for the resolving of public fears and concerns about vaccine safety, which is the cause of the decreased vaccination rates in developed countries.

Many false side effects have been attributed to vaccines by pseudoscience and fraudulent scientists (such as autism and the MMR vaccine, by Andrew Wakefield). This has caused tremendous harm to vaccination programs throughout the world. However, while vaccines are not without risk, sadly, the public hysteria about false vaccine risks often overshadows the challenges of detecting the real risks [8]. Vaccines face more strict safety standards than other pharmaceutical products as they are given to healthy populations of mostly children to prevent diseases. However, at the same time, due to the high effectiveness of vaccination programs, the target diseases and the consequences that the vaccines protect from are not generally apparent to the general public any more [8]. This can thus give the impression that vaccines are no longer necessary, while they can potentially cause harm. What the public does not realize is that actual serious side effects, which are extremely rare, are unlikely to be detected in the pre-licensing phases of vaccine testing, as the number of test subjects is simply too small; i.e., the power of the study is too low. In other words, pre-licensing studies can provide excellent estimates of efficiency, but they cannot rule out any very rare side effects $[8,9]$. This is demonstrated by three notable cases of vaccine retraction due to side effects that were revealed in the post-licensing phase, which have received surprisingly little public attention [8]: (i) a rotavirus vaccine from Wyeth Lederle (RotaShield) was retracted in 1999 for causing intussusception (a very rare but serious side effect) in infants; (ii) in 2007, it was found out that infants immunized with the combined MMR plus Varicella virus vaccine resulted in a greater risk of febrile seizures compared to those who received the conventional MMR vaccine; and (iii) after extensive vaccination of almost the entire populations of Finland and Sweden with the GlaxoSmithKline H1N1 vaccine Pandemrix, a steep increase in the incidence of the otherwise very rare autoimmune disease of narcolepsy was seen. After extensive investigations, the European Medicines Agency (EMA) confirmed an association between the GlaxoSmithKline H1N1 vaccine and narcolepsy, which was later also detected in England, Ireland, France and Norway. However, the causal mechanisms remain unclear in this case [10].

The knowledge from the fields of vaccinomics and adversomics will be of the utmost importance in the process of the development and testing of the COVID-19 vaccines. A wide range of physiological and pathological responses to the infection with SARS-CoV-2, observed in different individuals, indicates that genetic factors play a key role in the modulation of the immune response to this virus. Thus, we might predict that the same genetic factors will be involved in the vaccine response. Consequently, the use of vaccinomics and adversomics in the vaccine design will facilitate the development of a safe and effective COVID-19 vaccine. 
The aim of this report is to explore the contemporary scientific literature on the three mostcontroversial vaccines from the vaccinomic and adversomic aspects: those against Hepatitis B virus (HBV), MMR viruses, and human Papilloma virus (HPV).

\section{Vaccinomics}

The current vaccination schemes do not take into account interindividual differences in vaccine efficacy. Thus, all individuals are vaccinated with the same number of doses, even though some individuals might achieve seroconversion with a lower number of vaccine doses, while others might remain unresponsive even after administration of the standard number of doses. Therefore, prediction of vaccine efficiency before the administration of the vaccine to any particular individual might be useful for health and economic reasons. Individuals deemed to be unresponsive by vaccinomic tests could then be given a further vaccine dose while monitoring for seroconversion to assure that they are protected against the disease. On the other hand, hyper-responsive individuals might be vaccinated with a smaller number of doses, which would be beneficial from the economic point of view.

\subsection{Vaccinomics of the Hepatitis B Virus Vaccine}

Although seroconversion after three doses of the HBV vaccine is relatively high [11], inadequate production of protective antibodies has been observed for $4 \%$ to $10 \%$ of healthy individuals [12]. The number of non-responders is even higher in patients with autoimmune diseases $[13,14]$. Recently, the hypothesis has been proposed that HBV vaccine nonresponse might predict latent autoimmunity [15].

A relatively large number of vaccinomic studies have been conducted in connection with $\mathrm{HBV}$, some of which were carried out even before the term vaccinomics was coined. However, the majority of these focused on $\mathrm{HBV}$ vaccine efficacy, i.e., predicting good versus poor responses in terms of seroconversion on the basis of genetic markers. The immune response to the HBV vaccine shows a high level of heritability (77\%), as was determined in 207 twin pairs [16]. Early studies identified individuals as HBV vaccine poor responders who expressed high levels of the human leukocyte antigen HLA-DR3 and HLA-DR7 antigens (i.e., homozygous for haplotypes HLA-B8, SC01, DR3, HLA-B44, FC31, and DR7) [17,18]. In later studies, it was determined that the most important $H L A$ locus for HBV vaccine response prediction was $H L A-D R B 1^{*}$ [19] and that certain alleles at this locus are linked to nonresponse and others to good response to HBV vaccine. In several studies, alleles HLA-DRB1*0301, HLA-DRB1*0701, and $H L A-D Q B 1^{*} 0201$ were associated with no production of anti-HBV antibodies after vaccination (HBV vaccine nonresponse), while alleles $H L A-D R B 1^{*} 01, H L A-D R B 1^{*} 11$, and $H L A-D R B 1^{*} 15$ were associated with rapid production of protective antibodies (HBV vaccine good response) $[19,20]$. Functional studies have revealed that in humans, the mechanism of nonresponse for the HLA-DRB1*0301 and HLA-DRB1*0701 alleles was due to the lack of specific $\mathrm{T}$ cells that recognized a particular major histocompatibility complex (MHC)/HBV surface antigen peptide complex, rather than due to the failure of the MHC molecule to bind the HBV surface antigen peptide, as shown in a mouse model [21].

As conventional HLA typing is complex and time-consuming, the use of single nucleotide polymorphisms (SNPs) as vaccinomic markers that can be defined using simple genotyping methods (e.g., TaqMan technology) would be more suitable for clinical implementation. Indeed, genome-wide association studies (GWAS) have detected SNPs in the HLA genes that are in line with the older studies mentioned above and have great potential to be used as vaccinomic markers. In GWAS on an Indonesian cohort, two SNPs in HLA-DQB1 ( $r$ s32734227, rs32734289) were identified as markers of HBV vaccine nonresponse [22], while a genome wide association study (GWAS) on a Han Chinese population revealed rs477515 at HLA-DRB1 to be an independent marker of nonresponse to the HBV vaccine [23]. In a population of adult non-responders to infants given the HBV vaccine, a GWAS by Wu et al. detected a SNP at the HLA-DPB1 locus (rs7770370) as a nonresponse marker to the HBV vaccine booster dose [24]. Recently, a GWAS on Japanese individuals identified $H L A$ alleles of poor response to $\mathrm{HBV}$ vaccine as $D R B 1^{*} 0405, D Q B 1^{*} 0401$, and $D P B 1^{*} 0501$ [25]. As all of these GWASs were 
performed in Asian populations, the relevance of the genetic markers identified needs to be validated in Caucasians and Africans.

Apart from $H L A$ loci, other genes have been shown to influence HBV vaccine responses. For example, null alleles of the complement component $C 4 A$ gene ( $C 4 A Q 0$; due to deletion or non-expression) have been associated with poor response to the HBV vaccine [26]. Furthermore, Toll-like receptors (TLRs) and cytokines and their receptors have been identified as potential vaccinomics markers. The interleukin (IL)-1Bhaplotype $r s 1143633$ (A) + rs1143627 (G) was associated with HBV vaccine non-response, as well as SNPs in genes encoding IL-13 (rs1295686) and IL-4 (rs2243248). Conversely, rs1805015 for the IL-4 receptor (IL4RA) and $r s 3804100$ for TLR2 were associated with a good response to the HBV vaccine [27]. Several other loci have been connected to HBV vaccine nonresponse in different GWASs, although the studies will need replication before these can be conclusively considered as vaccinomic markers. Interestingly, a SNP in the butyrophilin like (BTNL)2 gene (rs3763316) was among the top hits in two independent GWASs [22,23], which indicates its potential as a useful vaccinomics marker. A recent GWAS on the Japanese population identified another SNP in the same gene ( $r$ s4248266) as a predictor of HBV vaccine response [25]. This gene encodes an MHC-II-associated, type I transmembrane protein. This is believed to be involved in immune surveillance, by serving as a negative $\mathrm{T}$ cell regulator through decreasing $\mathrm{T}$ cell proliferation and cytokine release. More details of the genes associated or believed to be associated with HBV vaccine responses are given in Tables $1-4$.

\subsection{Vaccinomics of the MMR Vaccine}

Despite the availability of a highly effective measles vaccine, a resurgence of measles has been seen across the developed world. Most of these cases can be attributed to non-vaccinated individuals (usually due to the fears spread by the antivaccine movements), although some of those infected had been fully vaccinated. Numerous studies have shown that host genetic factors result in inter-individual variations in measles-vaccine-induced antibodies, and hence can have a role in vaccine failure. 
Table 1. Details of HLA genes associated with HBV and MMR vaccine efficacies and safety. HLA: human leukocyte antigen; HBV: Hepatitis B virus; MMR: measles, mumps, and rubella.

\begin{tabular}{|c|c|c|c|c|c|c|c|}
\hline \multirow[t]{2}{*}{ Gene } & \multirow[t]{2}{*}{ Gene Description } & \multirow{2}{*}{$\begin{array}{l}\text { Genomic } \\
\text { Location }\end{array}$} & \multirow[t]{2}{*}{ Function of Gene Product } & \multirow{2}{*}{$\begin{array}{c}\text { Associated Disease } \\
\text { Phenotypes-Not Vaccine } \\
\text { Related [28] }\end{array}$} & \multicolumn{2}{|c|}{$\begin{array}{l}\text { Studies on Associated } \\
\text { Vaccinomic Phenotypes }\end{array}$} & \multirow{2}{*}{$\begin{array}{c}\text { Studies on Associated } \\
\text { Adversomics Phenotypes } \\
\text { HBV }\end{array}$} \\
\hline & & & & & HBV & MMR & \\
\hline$H L A-D R B 1$ & $\begin{array}{l}\text { Major histocompatibility } \\
\text { complex, class II, DR } \beta 1\end{array}$ & $6 \mathrm{p} 21.32$ & $\begin{array}{l}\text { HLA class II } \beta \text { chain } \\
\text { paralogue, presenting } \\
\text { peptides derived from } \\
\text { extracellular proteins }\end{array}$ & $\begin{array}{l}\text { Sarcoidosis, multiple sclerosis, } \\
\text { rheumatoid arthritis, } \\
\text { autism/schizophrenia }\end{array}$ & {$[17-21,23,25]$} & {$[29,30]$} & {$[31,32]$} \\
\hline$H L A-D Q B 1$ & $\begin{array}{l}\text { Major histocompatibility } \\
\text { complex, class II, DQ } \beta 1\end{array}$ & $6 \mathrm{p} 21.32$ & $\begin{array}{l}\text { HLA class II } \beta \text { chain } \\
\text { paralogue, presenting } \\
\text { peptides derived from } \\
\text { extracellular proteins }\end{array}$ & $\begin{array}{l}\text { Celiac disease, multiple sclerosis, } \\
\text { Creutzfeldt-Jakob disease, systemic } \\
\text { lupus erythematosus, } \\
\text { autism/schizophrenia }\end{array}$ & {$[17-20,22,25]$} & [30] & [31] \\
\hline$H L A-D P B 1$ & $\begin{array}{l}\text { Major histocompatibility } \\
\text { complex, class II, DP } \beta 1\end{array}$ & $6 \mathrm{p} 21.32$ & $\begin{array}{l}\text { HLA class II } \beta \text { chain } \\
\text { paralogue, presenting } \\
\text { peptides derived from } \\
\text { extracellular proteins }\end{array}$ & $\begin{array}{l}\text { Chronic beryllium disease, } \\
\text { Wegener granulomatosis, chronic } \\
\text { hepatitis B infection }\end{array}$ & {$[24,25]$} & {$[30,33]$} & None \\
\hline$H L A-B$ & $\begin{array}{l}\text { Major histocompatibility } \\
\text { complex, class I, B }\end{array}$ & $6 \mathrm{p} 21.33$ & $\begin{array}{l}\text { HLA class I heavy chain } \\
\text { paralogue, presenting } \\
\text { peptides derived from the } \\
\text { endoplasmic reticulum lumen }\end{array}$ & $\begin{array}{l}\text { Behcet disease, pulmonary arterial } \\
\text { hypertension, toxic epidermal } \\
\text { necrolysis, spondyloarthropathy, } \\
\text { Stevens-Johnson syndrome, } \\
\text { Takayasu arteritis }\end{array}$ & None & {$[29,30]$} & None \\
\hline$H L A-D Q A 1$ & $\begin{array}{l}\text { Major histocompatibility } \\
\text { complex, class II, DQ } \alpha 1\end{array}$ & $6 \mathrm{p} 21.32$ & $\begin{array}{l}\text { HLA class II } \alpha \text { chain } \\
\text { paralogue, presenting } \\
\text { peptides derived from } \\
\text { extracellular proteins }\end{array}$ & $\begin{array}{c}\text { Myasthenia gravis, celiac disease, } \\
\text { idiopathic achalasia }\end{array}$ & None & {$[29,30]$} & None \\
\hline$H L A-A$ & $\begin{array}{l}\text { Major histocompatibility } \\
\text { complex, class I, A }\end{array}$ & $6 \mathrm{p} 22.1$ & $\begin{array}{l}\text { HLA class I heavy chain } \\
\text { paralogue, presenting } \\
\text { peptides derived from the } \\
\text { endoplasmic reticulum lumen }\end{array}$ & $\begin{array}{c}\text { Cancers, birdshot } \\
\text { chorioretinopathy, myelodysplastic } \\
\text { syndrome, toxic epidermal } \\
\text { necrolysis }\end{array}$ & None & [30] & None \\
\hline$H L A-D P A 1$ & $\begin{array}{l}\text { Major histocompatibility } \\
\text { complex, class II, DP } \alpha 1\end{array}$ & $6 \mathrm{p} 21.32$ & $\begin{array}{l}\text { HLA class II } \alpha \text { chain } \\
\text { paralogue, presenting } \\
\text { peptides derived from } \\
\text { extracellular proteins }\end{array}$ & Granulomatosis with polyangiitis & None & [30] & None \\
\hline
\end{tabular}


Table 2. Details of genes encoding cytokines and their receptors associated with HBV and MMR vaccine efficacies and safety.

\begin{tabular}{|c|c|c|c|c|c|c|c|}
\hline Gene & Gene Description & $\begin{array}{l}\text { Genomic } \\
\text { Location }\end{array}$ & Gene Product Function & $\begin{array}{l}\text { Associated Disease Phenotypes- } \\
\text { Not Vaccine Related [28] }\end{array}$ & \multicolumn{2}{|c|}{$\begin{array}{l}\text { Studies on Associated } \\
\text { Vaccinomic Phenotypes }\end{array}$} & $\begin{array}{c}\text { Studies on Associated } \\
\text { Adversomics Phenotypes } \\
\text { MMR }\end{array}$ \\
\hline$T N F$ & Tumour necrosis factor & $6 \mathrm{p} 21.33$ & $\begin{array}{l}\text { Cytokine, regulation of cell } \\
\text { proliferation, differentiation, apoptosis, } \\
\text { lipid metabolism, coagulation }\end{array}$ & Asthma, malaria susceptibility, migraine & None & [34] & None \\
\hline TNFRSF1A & $\begin{array}{c}\text { TNF receptor } \\
\text { superfamily member } 1 \mathrm{~A}\end{array}$ & 12 p13.31 & $\begin{array}{l}\text { TNF receptor, cell survival, apoptosis, } \\
\text { and inflammation }\end{array}$ & $\begin{array}{l}\text { Intermittent hydrarthrosis, multiple } \\
\text { sclerosis, familial periodic fever, TNF } \\
\text { receptor } 1 \text { associated periodic syndrome }\end{array}$ & None & [34] & None \\
\hline IL-6 & Interleukin 6 & $7 \mathrm{p} 15.3$ & $\begin{array}{l}\text { Cytokine, inflammation, } \\
\text { and maturation of B cells }\end{array}$ & $\begin{array}{l}\text { Arteriovenous malformations of the brain, } \\
\text { diabetes mellitus type I, Crohn's disease, } \\
\text { Kaposi sarcoma, juvenile rheumatoid } \\
\text { arthritis, juvenile idiopathic arthritis }\end{array}$ & None & [34] & None \\
\hline$I L-1 \beta$ & Interleukin $1 \beta$ & 2q14.1 & $\begin{array}{l}\text { Cytokine, mediator of } \\
\text { inflammatory responses }\end{array}$ & $\begin{array}{l}\text { Gastric cancer risk (Helicobacter pylori } \\
\text { induced), periodontal disease }\end{array}$ & [27] & [34] & None \\
\hline IL-13 & Interleukin 13 & $5 q 31.1$ & $\begin{array}{l}\text { Cytokine, B cell maturation, promotion } \\
\text { of IgE isotype switching of B cells }\end{array}$ & Asthma, allergic rhinitis & [27] & None & None \\
\hline$I L-4$ & Interleukin 4 & $5 q 31.1$ & $\begin{array}{l}\text { Cytokine, B cell activation, } \\
\text { IgE secretion }\end{array}$ & $\begin{array}{l}\text { Allergic bronchopulmonary aspergillosis, } \\
\text { schistosomiasis }\end{array}$ & [27] & None & None \\
\hline$I L 4 R A$ & Interleukin 4 receptor & $16 \mathrm{p} 12.1$ & $\begin{array}{l}\text { Receptor for IL-4 and IL-13, promotes } \\
\text { Th2 differentiation }\end{array}$ & $\begin{array}{l}\text { Atopy, human immunodeficiency } \\
\text { virus - } 1 \text { resistance }\end{array}$ & [27] & None & None \\
\hline$I L 2 R A$ & $\begin{array}{l}\text { Interleukin } 2 \text { receptor } \\
\quad \text { subunit } \alpha\end{array}$ & 10p15.1 & $\begin{array}{l}\text { Part of IL-2 receptor, T cell-mediated } \\
\text { immune responses }\end{array}$ & $\begin{array}{l}\text { Diabetes mellitus type I, } \\
\text { immunodeficiency, juvenile } \\
\text { idiopathic arthritis }\end{array}$ & None & [34] & None \\
\hline $\operatorname{IL} 2 R B$ & $\begin{array}{l}\text { Interleukin } 2 \text { receptor } \\
\text { subunit } \beta\end{array}$ & 22q12.3 & $\begin{array}{l}\text { Part of IL2 receptor, T cell-mediated } \\
\text { immune response }\end{array}$ & $\begin{array}{l}\text { Juvenile idiopathic arthritis, } \\
\text { immunodeficiency }\end{array}$ & None & [34] & None \\
\hline IFNB1 & Interferon $\beta 1$ & 9 p21.3 & $\begin{array}{l}\text { Cytokine, defense against viral } \\
\text { infections, cell differentiation, } \\
\text { anti-tumor defense }\end{array}$ & Multiple sclerosis & None & [34] & None \\
\hline INFAR1 & $\begin{array}{l}\text { Interferon } \alpha / \beta \text { receptor } \\
\text { subunit } 1\end{array}$ & $21 q 22.11$ & $\begin{array}{l}\text { One of two chains of a receptor for } \\
\text { INF } \alpha \text { and INF } \beta \text {, activation of receptor } \\
\text { stimulates Janus protein kinases, which } \\
\text { phosphorylate STAT1 and STAT2 }\end{array}$ & $\begin{array}{l}\text { Hepatitis } C \text { susceptibility, } \\
\text { measles susceptibility }\end{array}$ & None & None & [35] \\
\hline INFAR2 & $\begin{array}{l}\text { Interferon } \alpha / \beta \text { receptor } \\
\text { subunit } 2\end{array}$ & $21 q 22.11$ & $\begin{array}{l}\text { One of two chains of a receptor for } \\
\text { INF } \alpha \text { and INF } \beta \text {, activation of receptor } \\
\text { stimulates Janus protein kinases, which } \\
\text { phosphorylate STAT1 and STAT2 }\end{array}$ & $\begin{array}{l}\text { Measles susceptibility, } \\
\text { immunodeficiency } 45\end{array}$ & None & None & [36] \\
\hline
\end{tabular}


Table 3. Details of genes encoding transcription factors and transcription regulators associated with MMR vaccine efficacy and safety.

\begin{tabular}{|c|c|c|c|c|c|c|}
\hline Gene & Gene Description & $\begin{array}{l}\text { Genomic } \\
\text { Location }\end{array}$ & Gene Product Function & $\begin{array}{l}\text { Associated Disease Phenotypes- } \\
\text { Not Vaccine Related [28] }\end{array}$ & $\begin{array}{c}\text { Studies on Associated } \\
\text { Vaccinomic Phenotype: } \\
\text { MMR }\end{array}$ & $\begin{array}{c}\text { Studies on Associated } \\
\text { Adversomics Phenotypes } \\
\text { MMR }\end{array}$ \\
\hline$R A R B$ & Retinoic acid receptor $\beta$ & $3 \mathrm{p} 24.2$ & $\begin{array}{c}\text { Nuclear transcriptional regulator, } \\
\text { binds retinoic acid }\end{array}$ & $\begin{array}{l}\text { Matthew-Wood syndrome, } \\
\text { microphthalmia, diaphragmatic hernia }\end{array}$ & [37] & None \\
\hline$R X R A$ & Retinoid $\mathrm{X}$ receptor $\alpha$ & $9 q 34.2$ & $\begin{array}{l}\text { Nuclear receptor, involvement in } \\
\text { retinoic-acid-mediated gene activation }\end{array}$ & $\begin{array}{c}\text { Colon adenoma, recessive dystrophic } \\
\text { Epidermolysis bullosa }\end{array}$ & [37] & None \\
\hline$V D R$ & Vitamin D receptor & $12 \mathrm{q} 13.11$ & $\begin{array}{l}\text { Ligand-inducible transcription factor, } \\
\text { also a receptor for the secondary bile } \\
\text { acid, lithocholic acid }\end{array}$ & $\begin{array}{l}\text { Hypocalcaemic vitamin D-resistant } \\
\text { rickets, osteoporosis, vitamin } \\
\text { D-dependent rickets (type 2a) }\end{array}$ & [37] & None \\
\hline TRIM25 & $\begin{array}{c}\text { Tripartite } \\
\text { motif-containing } 25\end{array}$ & $17 \mathrm{q} 23.1$ & $\begin{array}{l}\text { Transcription factor, mediates estrogen } \\
\text { actions in breast cancer }\end{array}$ & Influenza, swine influenza & [38] & None \\
\hline WT1 & $\begin{array}{l}\text { WT1 transcription } \\
\text { factor }\end{array}$ & $11 \mathrm{p} 13$ & $\begin{array}{l}\text { Transcription factor, development of } \\
\text { urogenital system, tumor } \\
\text { suppressor gene }\end{array}$ & $\begin{array}{l}\text { Gonadal dysgenesis, cancers, aniridia, } \\
\text { Denys-Drash syndrome, Frasier } \\
\text { syndrome, genetic steroid-resistant } \\
\text { nephrotic syndrome, Meacham } \\
\text { syndrome, ulcerative colitis, Wilms } \\
\text { tumor, aniridia, genitourinary } \\
\text { anomalies, and retardation syndrome }\end{array}$ & [39] & None \\
\hline STAT1 & $\begin{array}{l}\text { Signal transducer and } \\
\text { activator of } \\
\text { transcription } 1\end{array}$ & $2 \mathrm{q} 32.2$ & $\begin{array}{l}\text { Transcription activator, mediates } \\
\text { expression of a variety of genes, which } \\
\text { is thought to be important for cell } \\
\text { viability in response to pathogens, can } \\
\text { be activated by IFN } \alpha \text { and IFN } \gamma\end{array}$ & $\begin{array}{l}\text { Autoimmune enteropathy and } \\
\text { endocrinopathy, immunodeficiency 31A, } \\
\text { 31B, and 31C, susceptibility to viral and } \\
\text { mycobacterial infections }\end{array}$ & None & [40] \\
\hline STAT2 & $\begin{array}{l}\text { Signal transducer and } \\
\text { activator of } \\
\text { transcription } 2\end{array}$ & $12 \mathrm{q} 13.3$ & $\begin{array}{c}\text { Transcription activator, in response to } \\
\text { IFN, forms a complex with STAT1 } \\
\text { and ISGF3G }\end{array}$ & $\begin{array}{l}\text { Immunodeficiency 44, primary } \\
\text { immunodeficiency with } \\
\text { post-measles-mumps-rubella vaccine } \\
\text { viral infection }\end{array}$ & None & [41-43] \\
\hline IRF7 & $\begin{array}{l}\text { Interferon regulatory } \\
\text { factor } 7\end{array}$ & $11 \mathrm{p} 15.5$ & $\begin{array}{c}\text { Transcriptional activation of } \\
\text { virus-inducible cellular genes, } \\
\text { including IFN } \beta \text { chain genes }\end{array}$ & Immunodeficiency 39 & None & [44] \\
\hline IRF9 & $\begin{array}{l}\text { Interferon regulatory } \\
\text { factor } 9\end{array}$ & $14 q 12$ & $\begin{array}{l}\text { Transcription factor, mediates } \\
\text { signaling of IFN } \alpha \text { and IFN } \beta \text {, } \\
\text { IRF9/ISGF3G associates with the } \\
\text { phosphorylated STAT1:STAT2 dimer } \\
\text { to form ISGF3 transcription factor }\end{array}$ & $\begin{array}{l}\text { Immunodeficiency } 65 \text {, susceptibility to } \\
\text { viral infections }\end{array}$ & None & [45] \\
\hline
\end{tabular}


Table 4. Details of other genes associated with HBV and MMR vaccine efficacies and safety.

\begin{tabular}{|c|c|c|c|c|c|c|c|}
\hline \multirow[t]{2}{*}{ Gene } & \multirow[t]{2}{*}{ Gene Description } & \multirow{2}{*}{$\begin{array}{l}\text { Genomic } \\
\text { Location }\end{array}$} & \multirow[t]{2}{*}{ Gene Product Function } & \multirow{2}{*}{$\begin{array}{l}\text { Associated Disease Phenotypes- } \\
\text { Not Vaccine Related [28] }\end{array}$} & \multicolumn{2}{|c|}{$\begin{array}{c}\text { Studies on Associated } \\
\text { Vaccinomic Phenotypes }\end{array}$} & \multirow{2}{*}{$\begin{array}{c}\text { Studies on Associated } \\
\text { Adversomics Phenotype } \\
\text { MMR }\end{array}$} \\
\hline & & & & & HBV & MMR & \\
\hline$C D 46$ & CD46 molecule & $1 \mathrm{q} 32.2$ & $\begin{array}{l}\text { Cofactor activity for inactivation of } \\
\text { complement components C } 3 \mathrm{~b} \text { and } \mathrm{C} 4 \mathrm{~b} \\
\text { by serum factor I }\end{array}$ & $\begin{array}{l}\text { Atypical hemolytic uremic syndrome with } \\
\text { complement gene abnormality, hemolysis, } \\
\text { elevated liver enzymes, and a low platelet } \\
\text { count syndrome }\end{array}$ & None & {$[46,47]$} & [7] \\
\hline BTNL2 & Butyrophilin-like 2 & $6 \mathrm{p} 21.32$ & $\begin{array}{l}\text { MHC-II-associated, transmembrane } \\
\text { protein, negative T cell regulator }\end{array}$ & $\begin{array}{l}\text { Sarcoidosis, multiple sclerosis, } \\
\text { autism/schizophrenia }\end{array}$ & {$[22,23,25]$} & None & None \\
\hline$S L A M$ & $\begin{array}{l}\text { Signaling lymphocytic } \\
\text { activation molecule } \\
\text { family member } 1\end{array}$ & $1 \mathrm{q} 23.3$ & $\begin{array}{l}\text { Self-ligand receptor of signaling } \\
\text { lymphocytic activation molecule, } \\
\text { modulating the activation and } \\
\text { differentiation of a wide variety of } \\
\text { immune cells }\end{array}$ & $\begin{array}{l}\text { Measles susceptibility, subacute } \\
\text { sclerosing panencephalitis }\end{array}$ & None & [47] & None \\
\hline IFI44L & $\begin{array}{l}\text { Interferon-induced } \\
\text { protein } 44 \text { like }\end{array}$ & $1 \mathrm{p} 31.1$ & $\begin{array}{l}\text { Unknown, shown a low antiviral } \\
\text { activity against hepatitis } C \text { virus }\end{array}$ & $\begin{array}{l}\text { Lymph node tuberculosis, } \\
\text { Aicardi-Goutieres syndrome }\end{array}$ & None & {$[46]$} & [7] \\
\hline TLR4 & Toll-like receptor 4 & $9 q 33.1$ & $\begin{array}{l}\text { Pathogen recognition and activation of } \\
\text { innate immunity }\end{array}$ & Behcet's disease & None & {$[48]$} & None \\
\hline TLR2 & Toll-like receptor 2 & $4 q 31.3$ & $\begin{array}{l}\text { Pathogen recognition and activation of } \\
\text { innate immunity }\end{array}$ & $\begin{array}{l}\text { Leprosy susceptibility, } \\
\text { tuberculosis susceptibility }\end{array}$ & {$[27]$} & {$[48]$} & None \\
\hline KIAA1542 & $\begin{array}{l}\text { PHD and ring finger } \\
\text { domains } 1\end{array}$ & 11p15.5 & $\begin{array}{l}\text { Protein domain-specific binding and } \\
\text { RNA polymerase binding }\end{array}$ & Systemic lupus erythematosus & None & {$[48]$} & None \\
\hline TRIM5 & $\begin{array}{c}\text { Tripartite } \\
\text { motif-containing } 5\end{array}$ & 11p15.4 & $\begin{array}{l}\text { E3 ubiquitin-ligase, may have role in } \\
\text { retroviral restriction }\end{array}$ & $\begin{array}{l}\text { Rubella susceptibility, immune } \\
\text { deficiency disease }\end{array}$ & None & [38] & None \\
\hline TRIM22 & $\begin{array}{c}\text { Tripartite } \\
\text { motif-containing } 22\end{array}$ & $11 \mathrm{p} 15.4$ & Mediates interferon antiviral effects & $\begin{array}{l}\text { Rubella susceptibility, hepatitis } \\
\text { B susceptibility }\end{array}$ & None & [38] & None \\
\hline SCN1A & $\begin{array}{l}\text { Sodium voltage-gated } \\
\text { channel } \alpha \text { subunit } 1\end{array}$ & $2 \mathrm{q} 24.3$ & $\begin{array}{c}\text { Sodium channel } \alpha \text { subunit, regulates } \\
\text { sodium exchange between intracellular } \\
\text { and extracellular spaces, generation of } \\
\text { action potentials in muscle cells } \\
\text { and neurons }\end{array}$ & $\begin{array}{l}\text { Dravet syndrome, early infantile epileptic } \\
\text { encephalopathy 6, familial or sporadic } \\
\text { hemiplegic migraine, generalized epilepsy } \\
\text { with febrile seizures plus (type 2), } \\
\text { Lennox-Gastaut syndrome }\end{array}$ & None & None & [7] \\
\hline$S C N 2 A$ & $\begin{array}{l}\text { Sodium voltage-gated } \\
\text { channel } \alpha \text { subunit } 2\end{array}$ & $2 \mathrm{q} 24.3$ & $\begin{array}{c}\text { Sodium channel } \alpha \text { subunit, regulates } \\
\text { sodium exchange between intracellular } \\
\text { and extracellular spaces, generation of } \\
\text { action potentials in muscle cells } \\
\text { and neurons }\end{array}$ & $\begin{array}{l}\text { Benign familial infantile epilepsy, benign } \\
\text { familial neonatal-infantile seizures, Dravet } \\
\text { syndrome, early infantile epileptic } \\
\text { encephalopathy, generalized epilepsy with } \\
\text { febrile seizures-plus, West syndrome }\end{array}$ & None & None & [7] \\
\hline ANO3 & Anoctamin 3 & 11p14.2 & $\begin{array}{l}\text { Membrane protein, } \mathrm{Ca}^{2+} \text {-activated } \\
\text { chloride channel }\end{array}$ & $\begin{array}{l}\text { Cranio-cervical dystonia with laryngeal } \\
\text { and upper-limb involvement }\end{array}$ & None & None & [7] \\
\hline
\end{tabular}


Heritability of an antibody response to measles vaccination was estimated to be $88.5 \%$ in a twin study [49] and 49\% using the complete genetic information from a GWAS of 935 individuals [50]. This suggests that the inter-individual variations in antibody responses to measles vaccine arise through the combined small effects of many genes [50].

Early vaccinomic studies on the MMR vaccine mainly involved the genes that encode various cytokines and their receptors. As cytokines are important mediators of both adaptive and innate immune responses, it is not surprising that many SNPs in these genes were associated with responses to the MMR vaccine. Minor alleles of two polymorphisms in the tumor necrosis factor (TNF) (rs1799964) and IL-6 ( $r s 2069849$ ) genes were associated with low rates of expression of measles-specific antibodies after the MMR vaccine in a Somali population [34], while polymorphisms in $r s 2228149$ in IL-2 receptor subunit $\alpha(I L 2 R A)$ and $r s 1143634$ in IL-1B have been associated with low rates of expression mumps-specific antibodies [34]. Even more polymorphisms have been identified as associated with the nonresponses to the rubella component of the MMR vaccine: $r s 7873167, r s 3885423$, rs1364613 and rs1364612 in interferon (IFN)B1; rs12722713 and $r s 12722698$ in IL2RA; $r s 228937$ in IL2RB; rs2069824 in IL-6; and $r s 4149650$ in 'TNF receptor superfamily member $1 A^{\prime}$ ' (TNFRSF1A) [34]. At the same time, several polymorphisms of the HLA loci were addressed in association with the MMR vaccine response. Consistent associations with humoral responses to the measles component after two doses of MMR vaccine were shown in three independent cohorts for the following HLA alleles: $\mathrm{B}^{*} 3503$ (good response), and DQA1*0201 and $D R B 1^{*} 0701$ (poor responses) $[29,30]$. Distinct alleles of poor response were also detected for rubella and mumps components of the MMR vaccine: $\mathrm{A}^{*} 2705, \mathrm{~A}^{*} 5701, D P A 1^{*} 0201, D P B 1^{*} 0301, D P B 1^{*} 1301$ (rubella), and $D Q B 1^{*} 0303$ (mumps) [30]. Of interest, the association of the HLA-DPB1*0301 allele with the poor response to the rubella vaccine was replicated in a recent GWAS that investigated around five million variants in 1000 healthy individuals vaccinated with the MMR vaccine [33].

Furthermore, genes encoding proteins that interact with the measles virus (the wild and vaccine strains) and augment their entry into host cells were studied in the context of MMR vaccinomics. The most prominent genetic marker from this group of genes was $r$ s 2724384 in the CD46 gene, which was associated with low antibody response to MMR vaccination in both a candidate gene study on 764 individuals [47] and a GWAS on 2872 individuals [46]. While CD46 is preferentially used by the vaccine strain measles virus, 'signaling lymphocyte activation molecule' (SLAM) interacts more readily with the wild-type strain. In the candidate gene study, two SNPs in SLAM were associated with measles antibody levels, as well as the IFN- $\gamma$ and IL-10 responses [47]. In addition to CD46, one of the top hits in the GWAS here [46] was in the 'interferon-induced protein 44 like' (IFI44L) gene (rs273259). Interestingly, in the adversomic study by Feenstra et al. [7], the A allele of this polymorphism was associated with increased measles-specific antibody titer [46] and increased risk of febrile seizures after the MMR vaccination. The function of IFFI44L is still not clear, but it has been demonstrated that it has a type I IFN response against the hepatitis $C$ virus [51] and appears to be involved in innate immunity.

Toll-like receptors and their intracellular signaling molecules have important roles in innate immunity. Ovsyannikova et al. [48] examined associations between polymorphisms in TLR family genes and measles-vaccine-specific immune responses in 764 individuals vaccinated with two doses of MMR. Two SNPs in the coding regions of the TLR2 ( $r$ s3804100) and TLR4 ( $r 55030710)$ genes were associated with increases and decreases in measles-specific antibodies, respectively. Furthermore, the minor allele of a SNP in the KIAA1542 gene (rs702966) was associated with low IFN- $\gamma$ response [48].

Vitamin A (retinol) and vitamin D and their receptors are essential regulators of immune function, and they have been linked with susceptibility to various viral infections [52], and they have also been studied in the context of MMR vaccine efficiency [37]. In this study, several SNPs in retinoic acid receptor $\alpha(R A R B)$ were associated with variations in both measles antibodies and cytokine secretion levels, including IL-10, IFN- $\alpha$, and TNF- $\alpha$. Furthermore, significant associations were shown between multiple vitamin $\mathrm{D}$ receptors $(V D R)$ and retinoid $\mathrm{X}$ receptor $\alpha(R X R A) \mathrm{SNPs} /$ haplotypes and measles-specific IL-2, IL-6, IL-10, IFN- $\alpha$, IFN- $\gamma$, IFN $\lambda-1$, and TNF- $\alpha$ cytokine secretion [37]. 
The 'tripartite motif containing' TRIM proteins that are activated by type I IFNs were recently shown to be important cellular factors for innate immunity and antiviral defense [53]. Apparently, they also have roles in the MMR vaccine response, as associations have been shown between TRIM5 ( rs7122620) and TRIM25 (rs205499) gene polymorphisms and measles-specific antibody levels [38]. In the same study, several SNPs in TRIM5, 22 and 25 were connected with cytokine responses (IFN- $\gamma$, IL-2, IL-6, IL-10, TNF- $\alpha$ ).

Recently, a GWAS on 1843 individuals identified four polymorphisms in the tumour suppressor gene WT1 (rs4986811, rs5030172, rs5030157, rs5030166) that were associated with decreased rubella-specific IL-6 secretion from peripheral blood mononuclear cells post-MMR vaccine [39]. However, all four of these polymorphisms were identified in a WT1 transcript variant known to be a target of 'nonsense mediated decay', which indicates that its functional role in this vaccine response might be questionable.

In addition to genomic studies, whole transcriptome [54] and micro (mi)RNA profiling [55] have revealed interesting potential new vaccinomic markers. Next-generation sequencing of intracellular mRNA and miRNAs (mRNA-Seq) in measles-virus-stimulated B cells and CD4+ T cells from high and low antibody responders to measles vaccine identified vaccinomic markers from various gene ontology groups: plasma cell survival (CD93, IL6, CXCL12), chemokine/cytokine activity, and cell-cell communication/ adhesion/migration. The predicted targets for the identified B cell-specific miRNAs included the Fc-receptor and several other signalling pathways, as well as pathways related to transcriptional regulation, viral infection, lipid biosynthesis/metabolism, cytoskeletal protein binding, extracellular matrix-receptor interactions, and apoptosis.

In conclusion here, numerous HLA and non-HLA genetic factors that individually or jointly contribute to the variability seen for the humoral responses to the MMR vaccine have been identified. In the future, new approaches and methods will enable the investigation of immune response mechanisms to the measles vaccine on a new multidimensional level, such as vaccinomics, systems biology, GWAS, epitope prediction, and sophisticated bioinformatics/statistical algorithms, [56]. More details of the genes associated or believed to be associated with MMR vaccine responses are given in Tables $1-4$.

\subsection{Vaccinomics of the Human Papilloma Virus Vaccine}

Vaccination against HPV is intended for prevention of HPV-associated cancers. Vaccination is especially efficient against virus infection types 16 and 18, which are responsible for $70 \%$ of cervical cancers worldwide, and types 6 and 11, which are responsible for $90 \%$ of cases of genital warts. The Centers for Disease Control and Prevention recommends that all boys and girls get two doses of the HPV vaccine at 11 to 12 years old. To prevent HPV infection, there are currently three vaccines used for young girls from the age of 9 years: the bivalent vaccine Cervarix (directed at HPV types 16, 18), the quadrivalent vaccine Gardasil (directed at HPV type 6, 11, 16, 18) and Gardasil 9 (directed at HPV types $6,11,16,18,31,33,45,52,58$ ).

Since the HPV vaccines are relatively novel compared to the HBV and MMR vaccines, no vaccinomics studies have investigated the genetic markers of HPV vaccine efficiency to date. However, HLA and non-HLA genes have dominant roles in the initiation of the antiviral response through innate and humoral immunity networks, and they can also contribute to increased risk of the diseases. Leo et al. associated three haplotypes with increased risk for cervical neoplasia after HPV infection: HLA-DRB1*15/HLA-DQB1*0602/HLA-DQA1*0102, HLA-B*0702/HLA-C*0702 and HLA-DRB1*0401/ HLA-DQA1*0301 [57]. Mainali et al., investigated 191 men infected with HPV, and they identified novel susceptibility genes involved in HPV-16 pathogenesis for genital persistence. The strongest association was for intergenic variant $r s 1293153$ (between the AL133335.1 and DOK5 genes) and $r s 405103$ (in gene AC013565.1) on chromosomes 20 and 15, respectively [58]. Additionally, the genetic variants of transforming growth factor TGF 31 (T869C, C509T, and G915C) that have important roles in tumour progression and suppression and in immune suppression have been related to HPV-16-positive oropharyngeal cancer, as compared to their wild-type genotypes [59]. This was further supported by Levovitz et al., who reported that TGF $\beta R 1$ is significantly overexpressed in 
oropharyngeal and cervical cancer [60]. Altogether, these studies have shown the importance of the TGF $\beta 1$ signalling pathway in HPV tumour progression, and again, this highlights the involvement of the genetic background in HPV vaccine immune responses. These loci might thus represent good candidate genetic markers in vaccinomics and might be a starting point for evidence-based vaccination.

Recently, a critical review with novel insights and expert opinion on personalized HPV vaccination by Chambuso et al. identified two important strategies to personalization of HPV vaccination [61]: (a) identification of clinically important genetic markers for long-term HPV vaccine immune responses; and (b) profiling of host genetic risk factors that can contribute to modifications to long-term immune responses. Moreover, they also proposed some important research topics related to vaccine effectiveness and safety that should be addressed in the near future: the association between ethnic origin and impaired HPV vaccine immune responses; the correlation of post-vaccination serum antibodies with vaccine adverse effects; the variable persistence of immunity in different populations; the recognition of acute and chronic adverse events of HPV vaccination according to variations in host immune response genes and the number of vaccine doses administered [61].

\section{Adversomics}

Vaccines are a pharmaceutical product that is subjected to the strictest of safety protocols, as they are administered to healthy individuals, and in most cases to paediatric populations. Although modern vaccines have excellent safety profiles, some individuals do very rarely experience serious side effects after vaccination. These side effects are so rare that they can only be detected in the post-marketing phase of vaccine testing, when it has been administered to a very large number of individuals. According to the vaccine pharmacovigilance working groups of the Council for International Organisations of Medical Sciences/World Health Organisation [62], vaccine pharmacovigilance is defined as "the science and activities relating to the detection, assessment, understanding and communication of the adverse effects following immunization and other vaccine or immunization-related issues, and to the prevention of unwanted effects of the vaccine immunization". Investigation of the underlying causes of such events is essential not only to improve vaccine safety, but also to maintain public confidence in vaccination.

\subsection{Adversomics of the Hepatitis B Vaccine}

Generally, the safety of the HBV vaccine has been evaluated as very high $[63,64]$. However, over the last two decades following the launch of the massive HBV vaccination campaigns worldwide, there have been reports of the onset of several autoimmune diseases after the HBV administration. These have included: multiple sclerosis, optic neuritis, vasculitis, rheumatoid arthritis, systemic lupus erythematosus, and others. Multiple sclerosis and other demyelinating diseases have been investigated the most, and the majority of these studies have indicated no increased risk of multiple sclerosis after $\mathrm{HBV}$ vaccination [65]. However, the doubts about the HBV vaccine risks have not been resolved yet, also because there is good theoretical rationale for HBV-vaccine-induced autoimmunity through various mechanisms [66]. Furthermore, numerous studies on animal and human models have demonstrated activation of transient autoimmunity processes after HBV vaccination in terms of the levels of antibodies [67,68] and T-regulatory cells [69].

While a number of genetic markers that can predict HBV vaccine responses are known to date (i.e., for vaccine efficiency), there are very few related to prediction of adverse reactions to the HBV vaccine, as few such adversomics studies have been performed. Indeed, in general, HBV vaccine adversomic studies have been rare and of a more speculative nature. Belloni et al. concluded that there was no statistically significant difference in the levels of auto-antibodies between responders and non-responders for children vaccinated with the HBV vaccine [31]. However, the non-responder children showed a trend towards higher levels of anti-smooth-muscle antibodies ( $30 \%$ vs. $2 \%$ for responders). The anti-smooth-muscle antibody-positive non-responders all carried the supratype $H L A-C 4 A Q 0, D R B 1^{*} 0301, D Q B 1^{*} 02$, which has been associated with poor HBV response in other 
studies $[17,18,20]$ and is a well-known predisposing factor for autoimmune disorders. Belloni et al. speculated that HBV vaccine non-responders who carry the $H L A-C 4 A Q 0, D R B 1^{*} 0301, D Q B 1^{*} 02$ haplotype might thus be more at risk of autoimmune disease [31]. On the basis of the analysis of a series of case reports of various autoimmune diseases, Miller at al. hypothesized that the presence of certain HLA-DRB1 alleles $\left({ }^{*} 01: 01,{ }^{*} 03: 01,{ }^{*} 04: 01,{ }^{*} 13: 01,{ }^{*} 15: 01\right)$ that have been identified by others as HBV vaccine response modulators [17-20] can result in activation of CD8+T cells by HLA-A2-presented HBV surface antigens, which can result in the production of high levels of IFN- $\mathrm{Y}$ and TNF, and can promote autoimmune processes [32]. On the similar premise, Mormile hypothesized that infants who are non-responsive to HBV will be at risk for autoimmune disease later in life, and implicated SNPs in the genes for IL-18 and IFN- $\gamma$ as possible markers of this latent autoimmunity [15]. The concept that certain $H L A$ and $H L A$-associated alleles and haplotypes might predispose for nonresponse and autoimmunity after HBV vaccination is in part confirmed by a recent whole-genome transcriptomic study that showed that $\mathrm{HBV}$ vaccine non-responders had higher pre-vaccination expression levels of pro-inflammatory genes (especially those in the IFN pathways) compared to HBV vaccine responders [70]. More details of the descriptions of the genes associated or believed to be associated with HBV vaccine safety are given in Table 1.

\subsection{Adversomics of the MMR Vaccine}

Fever or elevated body temperature is one of the most frequent adverse events of vaccines. In particular, febrile seizures have been associated with the live-virus vaccines, such as MMR. While numerous studies have investigated the genetic basis of MMR vaccine efficiency, adversomic MMR studies remain scarce. One of the most encompassing was by Feenstra et al., who carried out a series of GWAS that compared the genetic make-up of children who experienced febrile seizures after the MMR vaccine to children with vaccine-unrelated febrile seizures, and to controls without a history of febrile seizures of any kind [7]. Two SNPs in two genes associated with MMR-related febrile seizures were identified: IFI44L ( $r$ s273259: $P=5.9 \times 10^{-12}$ vs. controls; $P=1.2 \times 10^{-9}$ vs. MMR-unrelated febrile seizures) and CD46 ( $r$ 1318653: $P=9.6 \times 10^{-11}$ vs. controls; $P=1.6 \times 10^{-9}$ vs. MMR-unrelated febrile seizures) [7]. Interestingly, as mentioned earlier, both of these genes were associated with efficiency of seroconversion after the MMR vaccine [46,47]. In the same study by Feenstra et al., three loci were associated with febrile seizures in general, as these loci differed between the controls and the MMR-vaccine-related seizures, as well as the controls and the MMR-vaccine-unrelated seizures, but not between the groups with MMR-vaccine-related and MMR-vaccine-unrelated seizures: SCN1A (rs6432860), SCN2A (rs3769955), and ANO3 (rs114444506) [7]. While SCN1A and SCN2A encode two subunits of a voltage-gated sodium channel and have already been associated with (febrile) seizures, ANO3 encodes one of the anoctamin proteins that form part of at least two $\mathrm{Ca}^{2+}$-activated chloride channels. Feenstra et al. also performed electrophysiological recordings on brain slices from wild-type and ANO3-null rats to investigate the mechanisms of ANO3 involvement in the genesis of febrile seizures. They reported that hippocampal neurons of ANO3-null rats showed increased excitability compared to neurons of wild-type rats at both normal and febrile body temperatures [7].

In extremely rare cases, MMR vaccination can lead to severe or chronic infections in children, which sometimes includes measles inclusion-body encephalitis, with the associated mortality rates as high as $10 \%$ to $20 \%$ [71]. This typically occurs in immunocompromised individuals, and is mostly due to inborn errors of immunity. T cell deficiencies, such as severe combined immune deficiency, have been associated with severe outcomes after MMR vaccine administration. However, such cases are particularly rare in clinical practice, as most patients with severe combined immune deficiency are diagnosed very early in life, and before administration of their first MMR vaccine dose [71]. Interestingly, in DiGeorge syndrome, where patients have mild-to-moderate T cell lymphopenia but intact $T$ cell function, no severe outcomes after MMR vaccination have been reported [71].

On the other hand, inborn errors of type I IFN immunity might be more important in this clinical setting considering severe infection after the MMR vaccine, as these conditions have milder presentation 
and are usually diagnosed later in life. Interestingly, an ontology-based literature mining study identified IFN- $\gamma$ as one of the top ranking genes in both vaccine and fever networks [72]. There have been a handful of case reports that have described mutations in genes in the IFN networks as a cause for severe adverse reactions to the MMR vaccine. In these case reports, mutations in the following genes have been associated with severe measles infection (and in some cases death) after MMR vaccine administration in otherwise healthy children without overt signs of immune deficiency: STAT1 [40], STAT2 [41-43], INFAR1 [35], INFAR2 [36], IRF7 [44] and IRF9 [45]. More detailed descriptions of the genes associated or believed to be associated with MMR vaccine safety are given in Tables $2-4$. Of note, the study that used ontology-based literature mining identified several other genes that have not yet been investigated in the scope of MMR vaccine adversomics as high ranking in both vaccine and fever networks (i.e., IL1B, TNF, IL-6, and CD8A), and in only fever networks (HSPA1A, NFKB1, IL-8, IL-2, MEFV, MAPK1, POMC, CD4, and IL-10), and in only vaccine networks (CSF2, IL7R, ERVWE1, $A P C, M C 4 R, I L 1 R 1$, and TLR2) [72]. In our opinion, these genes represent good candidates for future adversomic studies of the MMR vaccine.

\subsection{Adversomics of the Human Papilloma Virus Vaccine}

The HPV vaccines are considered safe and efficient. Since the initial approval of Gardasil by the US Food and Drug Administration in 2006, Gardasil, Gardasil 9 and Cervarix have all been through extensive safety testing in many clinical trials, which have included more than 29,000, 15,000 and 30,000 females and males, respectively [73]. As with other vaccines, the commonly reported side effects are mild. However, there have been a few well-described clinical cases of exacerbation of autoimmunerheumatic conditions after HPV vaccination, with particular reference to manifestation of systemic lupus erythematosus, and systemic-lupus-erythematosus-like disease [74,75]. The cases that have been reported have included females aged 13 to 32 years with a personal or family history of various autoimmunerheumatic conditions. This again highlights the importance of the genetic predisposition of the individual, with an environmental factor as a second hit to provoke autoimmune diseases. At the same time, it cannot be ignored that women with systemic lupus erythematosus show higher prevalence for HPV infection compared to healthy women, as the disease itself weakens the natural and humoral responses to infections [74,76]. Risk-benefit considerations need to be taken into account by physicians for each individual case, based on the depth of the anamnesis, the family history, and the genetic background prior to vaccination.

The recent literature also includes reviews of 'HPV vaccination syndrome' as a model for pathogenesis for fibromyalgia [77-79]. Fibromyalgia is defined as chronic widespread pain, which is commonly accompanied by joint stiffness, fatigue and sleep disturbance, along with cognitive, autonomic and sensory dysfunction. GWAS studies have identified two nonsense mutations here [80,81]: W32X in C110rf40 and Q100X in ZNFJJ. These have been associated with high levels of the cytokines that are involved in inflammation exacerbation.

\subsection{Biological Sex Differences in Adversomics}

It is now widely accepted that biological sex differences influence the type and strength of the immune response to a pathogen infection or in vaccination. Sex differences (e.g., sex, age, reproductive cycle, hormones, and genetic factors) affect all parts of the immune system-innate, humoral, and cellular response $[82,83]$. In general, compared to men and relevant for vaccination, women have a higher antibody response, an increased number of B cells, an increased number and activity of Treg and Tc cells and an increased number of macrophages with a higher release of pro-inflammatory cytokines. Despite the qualitative and quantitative senescence of the immune system, these differences persist from childhood to old age. For many vaccines, including HBV, HPV studies in women show increased antibody titres and more adverse reactions than men [84-86]. Another reason for a more intense immune response in women is the $\mathrm{X}$ chromosome, which contains a high density of immune-related genes. Although the second copy of the $\mathrm{X}$ chromosome in women is inactivated through the mechanisms of 
epigenetics, parts of it can be reactivated or skewed $X$ chromosome deactivation occurs $[87,88]$. Since both topics are highly relevant for the efficacy and side effects of the vaccine, for further details please refer to Flanagan et. al. [82] and Klein et. al. [89] and the references contained therein.

Despite all this knowledge, not many clinical vaccination studies take immunological differences into account. Data are usually combined, analyses by sex and gender are not considered or are not applicable due to the inequality of the samples. A rational design was proposed by Klein S.L. and Pekosz A. for influenza vaccination, taking into account biological sex differences [90]. In practice, the ultimate goal would be to reduce inflammation and side effects in women while maintaining efficient seroconversion; reducing vaccine doses in women would also mean greater availability of the vaccine within the population. At present, such a "male and female" vaccination approach seems to be a long way off. Many scientists and clinicians agree that such a rational design could have added value in terms of efficacy and adverse events; we also agree that it would be an important step forward in the field of personalized medicine.

\subsection{Challenges and Future Perspectives in Adversomics}

The lack of studies in the field of adversomics is at least in part due to the several challenges in the study design. The main problem that the researchers face is the question, which side effects of the vaccine are relevant to its safety and thus worth studying.

Mild side effects are not life threatening and can be an indicator of the efficient immune response to the vaccine, leading to the conclusion that they are not a priority in adversomic studies. On the other hand, even mild side effects can produce anxiety in patients and/or their parents and thus lead to the discontinuation of the vaccination, causing low vaccination rates. From this point of view, the determination of genetic markers of mild side effects of childhood vaccines might be rational. The ability to predict even mild side effects prior to vaccination might alleviate parental fears and lead to the increased trust in vaccination programmes and health system in general. Additional problem in studying mild side effects is that they tend to be underreported by health providers, leading to problems in cohort stratification. Therefore, in order to obtain relevant results the full cooperation of physicians in reporting even mild side effects of vaccinations is of the key importance.

On the other hand, serious side effects are usually promptly reported and the rationale for the identification of genetic markers predicting such side effects is clear. However, because serious side effects of vaccines are very rare in the population, the major challenge in such studies is collecting the sufficient number of cases to reach high enough statistical power. This might be overcame by using multicentric international approach, but unfortunately, different countries have heterogeneous systems and databases of reporting vaccine side effects, which leads to problems in the identification of the relevant cases. What is needed is the international database for vaccine side effects registration, which would enable relevant adversomic studies.

In conclusion, to enable the development of the field of vaccine adversomics the international database for reporting vaccine side effects accessible to researchers globally is needed, as well as full cooperation of health providers in reporting all vaccine side effects.

\section{Future Perspectives on Vaccinomics and Adversomics of a COVID-19 Vaccine}

At least eight types of vaccines are under development against SARS-CoV-2: virus vaccines (inactivated, weakened); viral vector vaccines (replicating, non-replicating); protein-based vaccines (protein subunit, virus-like particles); and nucleic acid vaccines (DNA, RNA). As of 11 May 2020, eight SARS-CoV-2 candidate vaccines were being tested on humans, and among these, the 'genetic immunization' with DNA or RNA vaccines shows potentially the most promising results. This approach is new for human use, and although there are several (non-COVID-19) DNA vaccines available for veterinary use, none of these have been approved for humans. However, important design knowledge has been obtained from several previous threats of such virus diseases, including from SARS-CoV in 2003, H5N1 avian influenza in 2005, H1N1 pandemic influenza in 2009, and Zika virus in 2016. 
This allowed DNA (Moderna) and RNA (mRNA; Inovio) SARS-CoV-2 vaccines to already be tested in clinical trials in April 2020. DNA-based and RNA-based vaccines should overcome some important safety worries and unwanted side effects as these do not contain any virus; instead, they include only the genetic material of the virus immunogenic protein (e.g., the 'spike protein' of SARS-CoV-2), which is inserted into human cells. After successful uptake of DNA, the human cell produces viral proteins that prompt an immune response, and thus protect against infection. Yu et al. have recently published promising results for their SARS CoV-2 DNA vaccine testing on 35 rhesus macaques [91]. The most significant reduction in viral replication was observed in the upper and lower respiratory tract, with full-length S immunogen after three doses of the vaccine (zero, one, and five weeks). The vaccinated animals developed humoral and cellular responses that included neutralizing antibody titres with comparable magnitude to the antibody titres in convalescent macaques and convalescent humans. A recent study on 149 COVID-19 convalescent individuals has also reported encouraging results; namely, even though the plasma titres of the neutralizing antibodies against the receptor binding domain of the SARS-CoV-2 spike protein were relatively low in most patients, they were present in all of the individuals tested, which suggests that a vaccine designed to elicit these antibodies should be broadly effective [92].

In our opinion, personalized approaches to SARS-CoV-2 vaccine development will be even more important than for other vaccines, as profound differences in the patient responses to SARS-CoV-2 infection have been reported since the early stages of the COVID-19 pandemic. While in most infected individuals relatively mild respiratory symptoms have been noted, a certain subpopulation of patients undergoes a severe cytokine storm that can lead to multi-organ failure and high levels of mortality. Several environmental and demographic factors have been attributed to these interindividual differences in COVID-19 severity, but there are some indications that genetic factors have an important role here. Considering SARS-CoV-2 vaccine development, it should be noted that patients who have severe reactions to the infection might be more at risk for adverse reactions to the vaccine (i.e., cytokine storm). Conversely, individuals with asymptomatic presentation might be potential vaccine non-responders. Thus, the genetic markers identified as predictors of COVID-19 severity should be taken into account during the vaccine development and its later administration.

In May 2020, an important international initiative called the 'COVID-19 Host Genetics Initiative' was started [93], which aims to determine host genetic factors that can explain interindividual differences in responses to SARS-CoV-2 infection, with particular focus on HLA genes. At time of writing (end of September 2020), 216 studies had joined the initiative, which is both retrospective and prospective in nature, and mostly centred on Europe and USA, with participation still expanding. Retrospective collections are typically biobanks that already include significant genetic data and active connections to health systems, while prospective collections have recently started to directly obtain consent from incoming COVID-19 patients. Retrospective collections enable rapid development of genetic studies on susceptibility and severity, while prospective approaches bring important additional opportunities not only for deeper DNA studies, but also for potentially informative viral and antibody profiling and epitope mapping experiments that can be implemented in vaccine development [93].

The angiotensin-converting enzyme-2 gene, $A C E 2$, has been hypothesized to have an important role in COVID-19 severity, as it was identified early on as a facilitator of the SARS-CoV-2 virus entry into cells. The ACE2 product, angiotensin-converting enzyme-2, has been shown to be the receptor for both SARS-CoV-2 virus and the NL63 human respiratory coronavirus. A recent study analyzed all of the 1700 variants in the ACE2 gene from the China Metabolic Analytics Project and 1000 Genomes Project databases. No direct evidence was found for coronavirus S-protein binding-resistant ACE2 mutants in different populations [94]. However, East Asian populations have much higher allelic frequencies of genetic variants associated with higher ACE2 expression in tissues, which indicates differential susceptibility to SARS-CoV-2 in different populations [94].

In contrast, an agnostic approach has revealed several genes of interest that might have roles in SARS-CoV-2 infection responses. A meta-analysis of two GWASs that involved patients with severe 
COVID-19 (as 835 and 775 individuals in the Italian and Spanish cohorts, respectively) and mostly non-infected controls from the general population (as 1255 and 950 individuals in the Italian and Spanish cohorts, respectively), revealed two critical loci that were responsible for severe COVID-19 presentation: 3p21.31 and 9q34.2. The 9q34.2 locus is associated with the ABO blood groups, which thus confirms the previous anecdotal observations of differential SARS-CoV-2 responses in individuals with different blood groups. In this meta-analysis, blood group A was associated with more severe disease, while blood group 0 was protective. However, the latest multi-institutional study on 7648 COVID-19-positive samples did not support the association of blood type with risk of intubation or death in COVID-19 patients, although it confirmed that blood type $\mathrm{O}$ was less common for SARS-CoV-2 infection [95]. Considering the first locus, 3p21.31, six genes have been defined for this area: SLC6A20, LZTFL1, CCR9, FYCO1, CXCR6, and XCR1 [96], some of which appear directly or indirectly connected to SARS-CoV-2 responses (Figure 1). SLC6A20 encodes sodium-proline transporter 1, which can functionally interact with ACE2, the SARS-CoV-2 cell-surface receptor. CCR9, XCR1 and CXCR6 encode chemokine receptors, the last of which regulates the specific location of lung-resident memory CD8 T cells throughout sustained immune responses to airway pathogens [96]. The functions of these other two genes at the 3p21.31 locus include protein trafficking (LZTFL1) and autophagy (FYCO1).

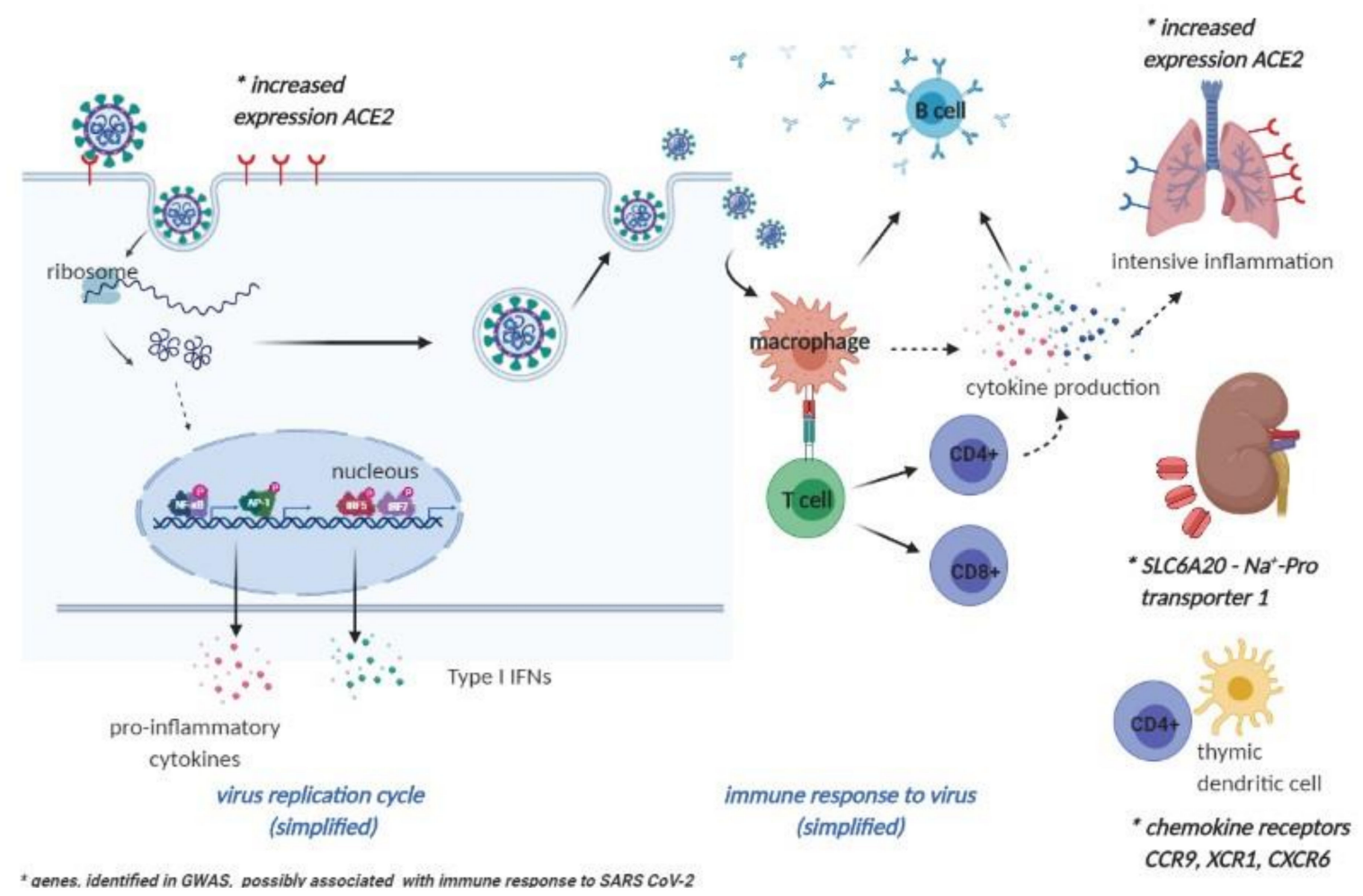

Figure 1. Genes identified in genome association studies (GWASs), possibly related to the immune response to SARS-CoV-2. (Adapted from "Coronavirus Replication Cycle", by BioRender.com (2020). Retrieved from https://app.biorender.com/biorender-templates).

Previously mentioned sex differences in immune response and hormonal status should not be neglected also in the infection with SARS-CoV2. In many states, reporting sex-disaggregated data, COVID-19 with severe disease symptoms and higher death rates are seen among men [97,98]. Recently, Takahashi $\mathrm{T}$ et al. provided us with findings, that poor $\mathrm{T}$ cell response is associated with worse disease outcome in male patients, but not in female patients. Additionally, higher levels of innate immune cytokines (Il-8 and IL-18) at the disease baseline and during the course of the disease (chemokine CCL5) were associated with worse disease progression in males. Results of this study have shown equality in humoral but diversities in cellular immune response as well as the levels of the effector molecules. 
The authors suggested that vaccines and therapies increasing $\mathrm{T}$ cell immune response to SARS-CoV-2 might be appropriate for male patients, and those dampening the innate immune activation in the early stage of the disease for females [99].

\section{Conclusions}

Vaccination has been one of the most successful public health interventions in human history, as it continues to save millions of lives every year. However, the effectiveness and safety of some vaccines is limited by the heterogeneity of the responses among different individuals and across different populations. Heterogeneity of vaccine responses is a multifactorial trait, which results from a combination of environmental and genetic factors. Several environmental factors that contribute to this variation have been identified, such as age, gender, ethnicity, body-mass index and health, and smoking status, as well as dose, route of administration and quality of storage of the vaccine. Twin studies have also identified high levels of heritability of vaccine responses. Thus, identification of the genetic factors that modulate responses to vaccine administration is of the utmost importance for the development of safe and effective vaccines, to increase the public trust in vaccines, and consequently to increase the background vaccination rates.

Author Contributions: Conceptualization, N.K.K.; methodology, N.K.K.; formal analysis, N.K.K.; investigation, N.K.K., J.O.; writing-original draft preparation, N.K.K., J.O.; writing-review and editing, N.K.K., J.O.; visualization, N.K.K., J.O.; supervision, N.K.K.; project administration, N.K.K., J.O. All authors have read and agreed to the published version of the manuscript.

Funding: This research received no external funding.

Acknowledgments: The authors acknowledge Chris Berrie for scientific editing of the manuscript.

Conflicts of Interest: The authors declare that they have no conflicts of interest. The sponsors had no role in the design, execution, interpretation, or writing of the study.

\section{References}

1. Precision Medicine Initiative. Available online: https://obamawhitehouse.archives.gov/precision-medicine (accessed on 25 September 2020).

2. Poland, G.A.; Ovsyannikova, I.G.; Jacobson, R.M. Application of Pharmacogenomics to Vaccines. Pharmacogenomics 2009, 10, 837-852. [CrossRef]

3. Hoffman, S.L.; Rogers, W.O.; Carucci, D.J.; Venter, J.C. From Genomics to Vaccines: Malaria as a Model System. Nat. Med. 1998, 4, 1351-1353. [CrossRef]

4. Poland, G.A.; Kennedy, R.B.; McKinney, B.A.; Ovsyannikova, I.G.; Lambert, N.D.; Jacobson, R.M.; Oberg, A.L. Vaccinomics, Adversomics, and the Immune Response Network Theory: Individualized Vaccinology in the 21st Century. Semin. Immunol. 2013, 25, 89-103. [CrossRef] [PubMed]

5. Poland, G.A.; Ovsyannikova, I.; Kennedy, R. Personalized Vaccinology: A Review. Vaccine 2018, 36, 5350-5357. [CrossRef]

6. Whitaker, J.A.; Ovsyannikova, I.G.; Poland, G.A. Adversomics: A New Paradigm for Vaccine Safety and Design. Expert Rev. Vaccines 2015, 14, 935-947. [CrossRef] [PubMed]

7. Feenstra, B.; Pasternak, B.; Geller, F.; Carstensen, L.; Wang, T.; Huang, F.; Eitson, J.L.; Hollegaard, M.V.; Svanström, H.; Vestergaard, M.; et al. Common Variants Associated With General and MMR Vaccine-Related Febrile Seizures. Nat. Genet. 2014, 46, 1274-1282. [CrossRef]

8. Kwok, R. Vaccines: The Real Issues in Vaccine Safety. Nature 2011, 473, 436-438. [CrossRef] [PubMed]

9. Jacobson, R.M.; Adegbenro, A.; Pankratz, V.; Poland, G.A. Adverse Events and Vaccination-the Lack of Power and Predictability of Infrequent Events in Pre-Licensure Study. Vaccine 2001, 19, 2428-2433. [CrossRef]

10. Barker, C.I.S.; Snape, M.D. Pandemic Influenza a H1N1 Vaccines and Narcolepsy: Vaccine Safety Surveillance in Action. Lancet Infect. Dis. 2014, 14, 227-238. [CrossRef]

11. Chen, D.-S. Hepatitis B Vaccination: The Key Towards Elimination and Eradication of Hepatitis B. J. Hepatol. 2009, 50, 805-816. [CrossRef] [PubMed]

12. Walayat, S.; Ahmed, Z.; Martin, D.; Puli, S.; Cashman, M.; Dhillon, S. Recent Advances in Vaccination of Non-Responders to Standard Dose Hepatitis B Virus Vaccine. World J. Hepatol. 2015, 7, 2503-2509. [CrossRef] 
13. Harrison, P. Hepatitis B Vaccine Ineffective in Most Patients with RA. In Proceedings of the European League Against Rheumatism (EULAR) Congress, Rome, Italy, 10-13 June 2015.

14. Vitaliti, G.; Praticò, A.D.; Cimino, C.; Di Dio, G.; Lionetti, E.; La Rosa, M.; Leonardi, S. Hepatitis B Vaccine in Celiac Disease: Yesterday, Today and Tomorrow. World J. Gastroenterol. 2013, 19, 838-845. [CrossRef]

15. Mormile, R.; Mormile, M.R. Hepatitis B Vaccine Non Response: A Predictor of Latent Autoimmunity? Med. Hypotheses 2017, 104, 45-47. [CrossRef]

16. Newport, M.; The MRC Gambia Twin Study Group; Goetghebuer, T.; Weiss, H.A.; Whittle, H.; Siegrist, C.-A.; Marchant, A. Genetic Regulation of Immune Responses to Vaccines in Early Life. Genes Immun. 2004, 5, 122-129. [CrossRef] [PubMed]

17. Alper, C.A.; Kruskall, M.S.; Marcus-Bagley, D.; Craven, D.E.; Katz, A.J.; Brink, S.J.; Dienstag, J.L.; Awdeh, Z.; Yunis, E.J. Genetic Prediction of Nonresponse to Hepatitis B Vaccine. N. Engl. J. Med. 1989, 321, 708-712. [CrossRef] [PubMed]

18. Kruskall, M.S. The Major Histocompatibility Complex: The Value of Extended Haplotypes in the Analysis of Associated Immune Diseases and Disorders. Yale J. Boil. Med. 1990, 63, 477-486.

19. Höhler, T.; Reuss, E.; Evers, N.; Dietrich, E.; Rittner, C.; Freitag, C.M.; Vollmar, J.; Schneider, P.M.; Fimmers, R. Differential Genetic Determination of Immune Responsiveness to Hepatitis B Surface Antigen and to Hepatitis a Virus: A Vaccination Study in Twins. Lancet 2002, 360, 991-995. [CrossRef]

20. Desombere, I.; Willems, A.; Leroux-Roels, G. Response to Hepatitis B Vaccine: Multiple HLA Genes Are Involved. Tissue Antigens 1998, 51, 593-604. [CrossRef]

21. Kruger, A.; Adams, P.; Hammer, J.; Böcher, W.O.; Schneider, P.M.; Rittner, C.; Hoehler, T. Hepatitis B Surface Antigen Presentation and HLA-DRB1*-Lessons from Twins and Peptide Binding Studies. Clin. Exp. Immunol. 2005, 140, 325-332. [CrossRef]

22. Davila, S.; Froeling, F.E.M.; Tan, A.; Bonnard, C.; Boland, G.J.; Snippe, H.; Hibberd, M.L.; Seielstad, M. New Genetic Associations Detected in a Host Response Study to Hepatitis B Vaccine. Genes Immun. 2010, 11, 232-238. [CrossRef]

23. Pan, L.; Zhang, L.; Zhang, W.; Wu, X.; Li, Y.; Yan, B.; Zhu, X.; Liu, X.; Yang, C.; Xu, J.; et al. A Genome-Wide Association Study Identifies Polymorphisms in the HLA-DR Region Associated with Non-Response to Hepatitis B Vaccination in Chinese Han Populations. Hum. Mol. Genet. 2013, 23, 2210-2219. [CrossRef]

24. Wu, T.-W.; Chen, C.-F.; Lai, S.-K.; Lin, H.H.; Chu, C.-C.; Wang, L.-Y. SNP rs7770370 inHLA-DPB1 Loci as a Major Genetic Determinant of Response to Booster Hepatitis B Vaccination: Results of a Genome-Wide Association Study. J. Gastroenterol. Hepatol. 2015, 30, 891-899. [CrossRef] [PubMed]

25. Nishida, N.; Sugiyama, M.; Sawai, H.; Nishina, S.; Sakai, A.; Ohashi, J.; Khor, S.-S.; Kakisaka, K.; Tsuchiura, T.; Hino, K.; et al. Key HLA-DRB1-DQB1 Haplotypes and Role of the BTNL2 Gene for Response to a Hepatitis B Vaccine. Hepatology 2018, 68, 848-858. [CrossRef]

26. Höhler, T.; Stradmann-Bellinghausen, B.; Starke, R.; Sänger, R.; Victor, A.; Rittner, C.; Schneider, P.M. C4 A Deficiency and Nonresponse to Hepatitis B Vaccination. J. Hepatol. 2002, 37, 387-392. [CrossRef]

27. Chen, J.; Liang, Z.; Lu, F.; Fang, X.; Liu, S.; Zeng, Y.; Zhu, F.; Chen, X.; Shen, T.; Li, J.; et al. Toll-Like Receptors and Cytokines/Cytokine Receptors Polymorphisms Associate With Non-Response to Hepatitis B Vaccine. Vaccine 2011, 29, 706-711. [CrossRef]

28. Ensembl. Available online: https://www.ensembl.org/index.html (accessed on 1 March 2018).

29. Ovsyannikova, I.G.; Pankratz, V.S.; Vierkant, R.A.; Jacobson, R.M.; Poland, G.A. Consistency of HLA Associations Between Two Independent Measles Vaccine Cohorts: A Replication Study. Vaccine 2012, 30, 2146-2152. [CrossRef]

30. Ovsyannikova, I.G.; Poland, G.A. Vaccinomics: Current Findings, Challenges and Novel Approaches for Vaccine Development. AAPS J. 2011, 13, 438-444. [CrossRef]

31. Belloni, C.; Avanzini, M.A.; De Silvestri, A.; Martinetti, M.; Pasi, A.; Coslovich, E.; Autelli, M.; Masanti, M.L.; Cuccia, M.; Tinelli, C.; et al. No Evidence of Autoimmunity in 6-Year-Old Children Immunized at Birth with Recombinant Hepatitis B Vaccine. Pediatrics 2002, 110, e4. [CrossRef]

32. Miller, J.D.; Whitehair, L.H. HypothesisConcurrent HLA- Related Response Factors Mediate Recombinant Hepatitis B Vaccine Major Adverse Events. Autoimmunity 2005, 38, 181-194. [CrossRef]

33. Scepanovic, P.; Alanio, C.; Hammer, C.; Hodel, F.; Bergstedt, J.; Patin, E.; Thorball, C.W.; Chaturvedi, N.; Charbit, B.; Abel, L.; et al. Human Genetic Variants and Age Are the Strongest Predictors of Humoral Immune Responses to Common Pathogens and Vaccines. Genome Med. 2018, 10, 1-13. [CrossRef] 
34. Dhiman, N.; Ovsyannikova, I.G.; Vierkant, R.A.; Pankratz, V.S.; Jacobson, R.M.; Poland, G.A. Associations Between Cytokine/Cytokine Receptor Single Nucleotide Polymorphisms and Humoral Immunity to Measles, Mumps and Rubella in a Somali Population. Tissue Antigens 2008, 72, 211-220. [CrossRef]

35. Hernandez, N.; Bucciol, G.; Moens, L.; Le Pen, J.; Shahrooei, M.; Goudouris, E.; Shirkani, A.; Changi-Ashtiani, M.; Rokni-Zadeh, H.; Sayar, E.H.; et al. Inherited IFNAR1 Deficiency in Otherwise Healthy Patients With Adverse Reaction to Measles and Yellow Fever Live Vaccines. J. Exp. Med. 2019, 216, 2057-2070. [CrossRef] [PubMed]

36. Duncan, C.J.A.; Mohamad, S.M.B.; Young, D.F.; Skelton, A.J.; Leahy, T.R.; Munday, D.C.; Butler, K.M.; Morfopoulou, S.; Brown, J.R.; Hubank, M.; et al. Human IFNAR2 deficiency: Lessons for antiviral immunity. Sci. Transl. Med. 2015, 7, 307ra154. [CrossRef] [PubMed]

37. Ovsyannikova, I.G.; Haralambieva, I.H.; Vierkant, R.A.; O’Byrne, M.M.; Jacobson, R.M.; Poland, G.A. Effects of Vitamin A and D Receptor Gene Polymorphisms/Haplotypes on Immune Responses to Measles Vaccine. Pharm. Genom. 2012, 22, 20-31. [CrossRef]

38. Ovsyannikova, I.G.; Haralambieva, I.H.; Vierkant, R.A.; O’Byrne, M.M.; Poland, G.A. Associations Between Polymorphisms in the Antiviral TRIM Genes and Measles Vaccine Immunity. Hum. Immunol. 2013, 74, 768-774. [CrossRef]

39. Voigt, E.; Haralambieva, I.H.; Larrabee, B.R.; Kennedy, R.B.; Ovsyannikova, I.G.; Schaid, D.J.; Poland, G.A. Polymorphisms in the Wilms Tumor Gene Are Associated With Interindividual Variations in Rubella Virus-Specific Cellular Immunity After Measles-Mumps-Rubella II Vaccination. J. Infect. Dis. 2018, 217, 560-566. [CrossRef]

40. Burns, C.; Cheung, A.; Stark, Z.; Choo, S.; Downie, L.; White, S.; Conyers, R.; Cole, T. A Novel Presentation of Homozygous Loss-of-Function STAT-1 Mutation in an Infant with Hyperinflammation-A Case Report and Review of the Literature. J. Allergy Clin. Immunol. Pract. 2016, 4, 777-779. [CrossRef] [PubMed]

41. Hambleton, S.; Goodbourn, S.; Young, D.F.; Dickinson, P.; Mohamad, S.M.B.; Valappil, M.; McGovern, N.; Cant, A.J.; Hackett, S.J.; Ghazal, P.; et al. STAT2 Deficiency and Susceptibility to Viral Illness in Humans. Proc. Natl. Acad. Sci. USA 2013, 110, 3053-3058. [CrossRef]

42. Moens, L.; Van Eyck, L.; Jochmans, D.; Mitera, T.; Frans, G.; Bossuyt, X.; Matthys, P.; Neyts, J.; Ciancanelli, M.; Zhang, S.-Y.; et al. A Novel Kindred with Inherited STAT2 Deficiency and Severe Viral Illness. J. Allergy Clin. Immunol. 2017, 139, 1995-1997. [CrossRef] [PubMed]

43. Shahni, R.; Cale, C.M.; Anderson, G.; Osellame, L.D.; Hambleton, S.; Jacques, T.S.; Wedatilake, Y.; Taanman, J.-W.; Chan, E.; Qasim, W.; et al. Signal Transducer and Activator of Transcription 2 Deficiency Is a Novel Disorder of Mitochondrial Fission. Brain 2015, 138, 2834-2846. [CrossRef]

44. Ciancanelli, M.J.; Huang, S.X.L.; Luthra, P.; Garner, H.; Itan, Y.; Volpi, S.; Lafaille, F.G.; Trouillet, C.; Schmolke, M.; Albrecht, R.A.; et al. Life-Threatening Influenza and Impaired Interferon Amplification in Human IRF7 Deficiency. Science 2015, 348, 448-453. [CrossRef] [PubMed]

45. Hernandez, N.; Melki, I.; Jing, H.; Habib, T.; Huang, S.S.; Danielson, J.; Kula, T.; Drutman, S.; Belkaya, S.; Rattina, V.; et al. Life-Threatening Influenza Pneumonitis in a Child With Inherited IRF9 Deficiency. J. Exp. Med. 2018, 215, 2567-2585. [CrossRef]

46. Haralambieva, I.H.; Ovsyannikova, I.G.; Kennedy, R.B.; Larrabee, B.R.; Zimmermann, M.T.; Grill, D.E.; Schaid, D.J.; Poland, G.A. Genome-Wide Associations of CD46 and IFI44L Genetic Variants with Neutralizing Antibody Response to Measles Vaccine. Hum. Genet. 2017, 136, 421-435. [CrossRef]

47. Ovsyannikova, I.G.; Haralambieva, I.H.; Vierkant, R.A.; O’Byrne, M.M.; Jacobson, R.M.; Poland, G.A. The Association of CD46, SLAM and CD209 Cellular Receptor Gene SNPs with Variations in Measles Vaccine-Induced Immune Responses: A Replication Study and Examination of Novel Polymorphisms. Hum. Hered. 2011, 72, 206-223. [CrossRef]

48. Ovsyannikova, I.G.; Haralambieva, I.H.; Vierkant, R.A.; Pankratz, V.S.; Jacobson, R.M.; Poland, G.A. The Role of Polymorphisms in Toll-Like Receptors and Their Associated Intracellular Signaling Genes in Measles Vaccine Immunity. Hum. Genet. 2011, 130, 547-561. [CrossRef] [PubMed]

49. Tan, P.-L.; Jacobson, R.M.; Poland, G.A.; Jacobsen, S.J.; Pankratz, V. Twin Studies of ImmunogenicityDetermining the Genetic Contribution to Vaccine Failure. Vaccine 2001, 19, 2434-2439. [CrossRef]

50. Schaid, D.J.; Haralambieva, I.H.; Larrabee, B.R.; Ovsyannikova, I.G.; Kennedy, R.B.; Poland, G.A. Heritability of Vaccine-Induced Measles Neutralizing Antibody Titers. Vaccine 2017, 35, 1390-1394. [CrossRef] [PubMed] 
51. Schoggins, J.W.; Wilson, S.J.; Panis, M.; Murphy, M.Y.; Jones, C.T.; Bieniasz, P.D.; Rice, C.M. A Diverse Range of Gene Products Are Effectors of the Type I Interferon Antiviral Response. Nature 2011, 472, 481-485. [CrossRef]

52. Mora, J.R.; Iwata, M.; Von Andrian, U.H. Vitamin Effects on the Immune System: Vitamins A and D Take Centre Stage. Nat. Rev. Immunol. 2008, 8, 685-698. [CrossRef]

53. Nisole, S.; Stoye, J.P.; Saï, A. TRIM Family Proteins: Retroviral Restriction and Antiviral Defence. Nat. Rev. Microbiol. 2005, 3, 799-808. [CrossRef]

54. Haralambieva, I.H.; Zimmermann, M.T.; Ovsyannikova, I.G.; Grill, D.E.; Oberg, A.L.; Kennedy, R.B.; Poland, G.A. Whole Transcriptome Profiling Identifies CD93 and Other Plasma Cell Survival Factor Genes Associated with Measles-Specific Antibody Response after Vaccination. PLoS ONE 2016, 11, e0160970. [CrossRef]

55. Haralambieva, I.H.; Kennedy, R.B.; Simon, W.L.; Goergen, K.M.; Grill, D.E.; Ovsyannikova, I.G.; Poland, G.A. Differential miRNA expression in B cells is associated with inter-individual differences in humoral immune response to measles vaccination. PLoS ONE 2018, 13, e0191812. [CrossRef]

56. Haralambieva, I.H.; Kennedy, R.B.; Ovsyannikova, I.G.; Whitaker, J.A.; Poland, G.A. Variability in Humoral Immunity to Measles Vaccine: New Developments. Trends Mol. Med. 2015, 21, 789-801. [CrossRef]

57. Leo, P.J.; Madeleine, M.M.; Wang, S.; Schwartz, S.M.; Newell, F.; Pettersson-Kymmer, U.; Hemminki, K.; Hallmans, G.; Tiews, S.; Steinberg, W.; et al. Defining the Genetic Susceptibility to Cervical NeoplasiaA Genome-Wide Association Study. PLoS Genet. 2017, 13, e1006866. [CrossRef]

58. Mainali, B.; Schabath, M.B.; Sudenga, S.L.; Ye, Y.; Wiener, H.W.; Villa, L.L.; Giuliano, A.R.; Shrestha, S. Variants in Immune-Related Genes and Genital HPV 16 Persistence in Men. Papillomavirus Res. 2019, 7, 11-14. [CrossRef]

59. Guan, X.; Sturgis, E.M.; Lei, D.; Liu, Z.; Dahlstrom, K.R.; Wei, Q.; Li, G. Association of TGF- Beta1 Genetic Variants with HPV16-Positive Oropharyngeal Cancer. Clin. Cancer Res. 2010, 16, 1416-1422. [CrossRef]

60. Levovitz, C.; Chen, D.; Ivansson, E.; Gyllensten, U.; Finnigan, J.P.; Alshawish, S.; Zhang, W.; Schadt, E.E.; Posner, M.R.; Genden, E.M.; et al. TGFbeta Receptor 1: An Immune Susceptibility Gene in HPV-Associated Cancer. Cancer Res. 2014, 74, 6833-6844.

61. Chambuso, R.S.; Rebello, G.; Kaambo, E. Personalized Human Papillomavirus Vaccination for Persistence of Immunity for Cervical Cancer Prevention: A Critical Review with Experts' Opinions. Front. Oncol. 2020, 10, 548. [CrossRef]

62. Council for International Organisations of Medical Sciences, World Health Organisation. Available online: https://cioms.ch/ (accessed on 25 September 2020).

63. Maglione, M.A.; Das, L.; Raaen, L.; Smith, A.; Chari, R.; Newberry, S.; Shanman, R.; Perry, T.; Goetz, M.B.; Gidengil, C. Safety of Vaccines Used for Routine Immunization of U.S. Children: A Systematic Review. Pediatrics 2014, 134, 325-337. [PubMed]

64. Stratton, K. Immunization Safety Review: Hepatitis B Vaccine and Demyelinating Neurological Disordres. In Immunization Safety Review: Hepatitis B Vaccine and Demyelinating Neurological Disordres; National Academic Press: Washington, DC, USA, 2002.

65. Mailand, M.T.; Frederiksen, J.L. Vaccines and Multiple Sclerosis: A Systematic Review. J. Neurol. 2017, 264, 1035-1050. [CrossRef]

66. Salemi, S.; D'Amelio, R. Could Autoimmunity Be Induced by Vaccination? Int. Rev. Immunol. 2010, 29, 247-269. [CrossRef]

67. Porobič, J.M.; Avcin, T.; Božič, B.; Kuhar, M.; Cucnik, S.; Zupancic, M.; Prosenc, K.; Kveder, T.; Rozman, B. Anti-Phospholipid Antibodies Following Vaccination with Recombinant Hepatitis B Vaccine. Clin. Exp. Immunol. 2005, 142, 377-380. [CrossRef]

68. Ravel, G.; Christ, M.; Horand, F.; Descotes, J. Autoimmunity, Environmental Exposure and Vaccination: Is There a Link? Toxicology 2004, 196, 211-216. [CrossRef]

69. De Wolf, A.C.M.T.; Van Aalst, S.; Ludwig, I.S.; Bodinham, C.L.; Lewis, D.J.; Van Der Zee, R.; Van Eden, W.; Broere, F. Regulatory T Cell Frequencies and Phenotypes Following Anti-Viral Vaccination. PLoS ONE 2017, 12, e0179942. [CrossRef]

70. Fourati, S.; Cristescu, R.; Loboda, A.; Talla, A.; Filali, A.; Railkar, R.; Schaeffer, A.K.; Favre, D.; Gagnon, D.; Peretz, Y.; et al. Pre-Vaccination Inflammation and B-Cell Signalling Predict Age-Related Hyporesponse to Hepatitis B Vaccination. Nat. Commun. 2016, 7, 10369. [CrossRef] 
71. Pöyhönen, L.; Bustamante, J.; Casanova, J.-L.; Jouanguy, E.; Zhang, Q. Life-Threatening Infections Due to Live-Attenuated Vaccines: Early Manifestations of Inborn Errors of Immunity. J. Clin. Immunol. 2019, 39, 376-390. [CrossRef]

72. Hur, J.; Özgür, A.; Xiang, Z.; Ehe, Y.O. Identification of Fever and Vaccine-Associated Gene Interaction Networks Using Ontology-Based Literature Mining. J. Biomed. Semant. 2012, 3, 18. [CrossRef]

73. Center for Disease Control and Prevention. Human Papilloma Virus-HPV Vaccination Is Safe and Effective. 2019. Available online: https://www.cdc.gov/hpv/parents/vaccinesafety.html (accessed on 18 July 2020).

74. Klumb, E.; Pinto, A.; Jesus, G.; Araujo, M.; Jascone, L.; Gayer, C.; Ribeiro, F.; Albuquerque, E.; Macedo, J. Are Women with Lupus at Higher Risk of HPV Infection? Lupus 2010, 19, 1485-1491. [CrossRef] [PubMed]

75. Soldevilla, H.; Briones, S.; Navarra, S. Systemic Lupus Erythematosus Following HPV Immunization or Infection? Lupus 2012, 21, 158-161. [CrossRef] [PubMed]

76. García-Carrasco, M.; Mendoza-Pinto, C.; Rojas-Villarraga, A.; Molano-González, N.; Vallejo-Ruiz, V.; Munguía-Realpozo, P.; Colombo, A.L.; Cervera, R. Corrigendum to ‘Prevalence of Cervical HPV Infection in Women with Systemic Lupus Erythematosus: A Systematic Review and Meta-Analysis. Autoimmun. Rev. 2019, 18, 437. [CrossRef]

77. Blitshteyn, S.; Brinth, L.; Hendrickson, J.E.; Martínez-Lavín, M. Autonomic Dysfunction and HPV Immunization: An Overview. Immunol. Res. 2018, 66, 744-754. [CrossRef]

78. Martínez-Lavín, M. HPV Vaccination Syndrome: A Clinical Mirage, or a New Tragic Fibromyalgia Model. Reumatol. Clín. 2018, 14, 211-214. [CrossRef]

79. Ryabkova, V.A.; Churilov, L.P.; Shoenfeld, Y. Neuroimmunology: What Role for Autoimmunity, Neuroinflammation, and Small Fiber Neuropathy in Fibromyalgia, Chronic Fatigue Syndrome, and Adverse Events after Human Papillomavirus Vaccination? Int. J. Mol. Sci. 2019, 20, 5164. [CrossRef] [PubMed]

80. Jones, K.D.; Gelbart, T.; Whisenant, T.C.; Waalen, J.; Mondala, T.S.; Iklé, D.N.; Salomon, D.R.; Bennett, R.M.; Kurian, S.M. Genome-Wide Expression Profiling in the Peripheral Blood of Patients with Fibromyalgia. Clin. Exp. Rheumatol. 2016, 34, S89-S98. [PubMed]

81. Park, E.; Kim, J.-Y.; Choi, S.; Kim, D.S.; Oh, Y.L. Carcinogenic Risk of Human Papillomavirus (HPV) Genotypes and Potential Effects of HPV Vaccines in Korea. Sci. Rep. 2019, 9, 1-9. [CrossRef]

82. Flanagan, K.L.; Fink, A.L.; Plebanski, M.; Klein, S.L. Sex and Gender Differences in the Outcomes of Vaccination over the Life Course. Annu. Rev. Cell Dev. Biol. 2017, 33, 577-599. [CrossRef] [PubMed]

83. Klein, S.L.; Flanagan, K.L. Sex Differences in Immune Responses. Nat. Rev. Immunol. 2016, 16, 626-638. [CrossRef]

84. Garly, M.-L.; Jensen, H.; Martins, C.L.; Balé, C.; Baldé, M.A.; Lisse, I.M.; Aaby, P. Hepatitis B Vaccination Associated with Higher Female Than Male Mortality in Guinea-Bissau: An Observational Study. Pediatric Infect. Dis. J. 2004, 23, 1086-1092.

85. Khalil, M.K.; Al-Mazrou, Y.Y.; Al-Ghamdi, Y.S.; Tumsah, S.; Al-Jeffri, M.; Meshkhas, A. Effect of Gender on Reporting of MMR Adverse Events in Saudi Arabia. East. Mediterr. Health J. 2003, 9, 152-158.

86. Martins, S.; Livramento, A.D.; Andrigueti, M.; Kretzer, I.F.; Machado, M.J.; Spada, C.; Treitinger, A. The Prevalence of Hepatitis B Virus Infection Markers and Socio-Demographic Risk Factors in HIV-Infected Patients in Southern Brazil. Rev. Soc. Bras. Med. Trop. 2014, 47, 552-558. [CrossRef]

87. Bianchi, I.; Lleo, A.; Gershwin, M.E.; Invernizzi, P. The X Cromosome and Immune Associated Genes. J. Autoimmun. 2012, 38, 187-192. [CrossRef]

88. Schurz, H.; Salie, M.; Tromp, G.; Hoal, E.G.; Kinnear, C.J.; Möller, M. The X Chromosome and Sex-Specific Effects in Infectious Disease Susceptibility. Hum. Genom. 2019, 13, 1-12. [CrossRef]

89. Klein, S.L.; Jedlicka, A.; Pekosz, A. The Xs and Y of Immune Responses to Viral Vaccines. Lancet Infect. Dis. 2010, 10, 338-349. [CrossRef]

90. Klein, S.L.; Pekosz, A. Sex-Based Biology and the Rational Design of Influenza Vaccination Strategies. J. Infect. Dis. 2014, 209, S114-S119. [CrossRef] [PubMed]

91. Yu, J.; Tostanoski, L.H.; Peter, L.; Mercado, N.B.; Mcmahan, K.; Mahrokhian, S.H.; Nkolola, J.P.; Liu, J.; Li, Z.; Chandrashekar, A.; et al. DNA Vaccine Protection Against SARS-Cov-2 in Rhesus Macaques. Science 2020, 369, 806-811. [CrossRef]

92. Robbiani, D.F.; Gaebler, C.; Muecksch, F.; Lorenzi, J.C.C.; Wang, Z.; Cho, A.; Agudelo, M.; Barnes, C.O.; Gazumyan, A.; Finkin, S.; et al. Convergent antibody responses to SARS-CoV-2 in convalescent individuals. Nature 2020, 584, 437-442. [CrossRef] 
93. The COVID-19 Host Genetics Initiative. A Global Initiative to Elucidate the Role of Host Genetic Factors in Susceptibility and Severity of the SARS-Cov-2 Virus Pandemic. Eur. J. Hum. Genet. 2020, 28, 715-718. [CrossRef]

94. Cao, Y.; Li, L.; Feng, Z.; Wan, S.; Huang, P.; Sun, X.; Wen, F.; Huang, X.; Ning, G.; Wang, W. Comparative Genetic Analysis of the Novel Coronavirus (2019-nCov/SARS-Cov-2) Receptor ACE2 in Different Populations. Cell Discov. 2020, 6, 1-4. [CrossRef]

95. Latz, C.A.; Decarlo, C.; Boitano, L.; Png, C.Y.M.; Patell, R.; Conrad, M.F.; Eagleton, M.; Dua, A. Blood type and outcomes in patients with COVID-19. Ann. Hematol. 2020, 99, 2113-2118. [CrossRef] [PubMed]

96. Ellinghaus, D.; Degenhardt, F.; Bujanda, L.; Buti, M.; Agustin, A.; Invernizzi, P.; Fernandez, J.; Prati, D.; Baselli, G.; Asselta, R.; et al. Genomewide Association Study of Severe Covid-19 with Respiratory Failure. N. Engl. J. Med. 2020. [CrossRef]

97. The COVID-19 Sex-Disaggregated Data Tracker. Available online: https://globalhealth5050.org/the-sexgender-and-covid-19-project/the-data-tracker/ (accessed on 31 October 2020).

98. Scully, E.P.; Haverfield, J.; Ursin, R.L.; Tannenbaum, C.; Klein, S.L. Considering How Biological Sex Impacts Immune Responses and COVID-19 Outcomes. Nat. Rev. Immunol. 2020, 20, 442-447. [CrossRef]

99. Takahashi, T.; Yale IMPACT Research Team; Ellingson, M.K.; Wong, P.; Israelow, B.; Lucas, C.; Klein, J.; Silva, J.; Mao, T.; Oh, J.E.; et al. Sex Differences in Immune Responses That Underlie COVID-19 Disease Outcomes. Nature 2020, 1-9. [CrossRef] [PubMed]

Publisher's Note: MDPI stays neutral with regard to jurisdictional claims in published maps and institutional affiliations.

(C) 2020 by the authors. Licensee MDPI, Basel, Switzerland. This article is an open access article distributed under the terms and conditions of the Creative Commons Attribution (CC BY) license (http://creativecommons.org/licenses/by/4.0/). 